\title{
THE ROLE OF PSYCHOLOGICAL CAPITAL IN PREDICTING AFFECTIVE COMMITMENT OF GENERATION Y
}

\section{Peran Psychological Capital dalam Memprediksi Komitmen Afektif pada Generasi $Y$}

\author{
Endro Puspo Wiroko \\ Psychology Faculty of Pancasila University \\ Article Received $22^{\text {th }}$ January 2019
}

\begin{abstract}
The present study investigated the role of psychological capital to affective commitment. Affective commitment is employee's emotional attachment to, identification with, and involvement in the organization. Psychological capital is positive psychological state of development and is characterized by self efficacy, optimism, hope, and resiliency. This is the first study to examine the role of psychological capital on affective commitment by using generation $Y$ in Jakarta as participants. They were 176 male and female employees who were varied in age, job level, employment status, tenure, educational background, and work location. Data was gathered by using two measures: psychological capital and affective commitment scale. Interestingly, this study revealed that psychological capital significantly predict affective commitment in statistical point of view but not in practical implication. Regression analysis reported that psychological capital contribute only $2 \%$ to affective commitment among Indonesian generation $Y$.
\end{abstract}

Keywords: affective commitment, psychological capital, generation $Y$

\begin{abstract}
ABSTRAK
Penelitian ini bertujuan untuk mengetahui peran modal psikologis terhadap komitmen afektif. Komitmen afektif adalah kelekatan emosional, identifikasi, dan keterlibatan karyawan dalam organisasi. Modal psikologis adalah kondisi positif perkembangan psikologis yang ditandai dengan efikasi diri, optimisme, harapan, dan resiliensi. Penelitian ini menjadi studi pertama yang menguji modal psikologis sebagai prediktor dari komitmen afektif dengan menggunakan generasi Y di Jakarta sebagai partisipan. Mereka adalah 183 karyawan pria dan wanita yang bervariasi dalam hal usia, tingkat jabatan, status karyawan, masa kerja, latar belakang pendidikan, dan lokasi kerja. Data diambil dengan menggunakan dua alat ukur: skala modal psikologis dan skala komitmen afektif. Menariknya, penelitian ini menunjukkan bahwa modal psikologis dapat memprediksi komitmen afektif dalam sudut pandang statistik tetapi tidak dalam implikasi praktis. Analisis regresi menunjukkan bahwa modal psikologis hanya memberikan kontribusi sebesar $2 \%$ terhadap komitmen afektif pada generasi Y di Indonesia.
\end{abstract}

Kata kunci: komitmen afektif, modal psikologis, generasi Y

\section{INTRODUCTION}

It is understood that there are three different generations in today's workplace,

\footnotetext{
*Author Correspondence:

E-mail:

endro.puspowiroko@univpancasila.ac.id
}

they are baby boomers (born in 1943-1960), generation X (1961-1979), and generation Y (1980-1994). Delcampo, Haggerty, Haney, \& Knippel (2011) mentioned that the proportion of generation $\mathrm{Y}$ is getting bigger in the future.

Generation $\mathrm{Y}$ had the proportion of $36 \%$ in 2014, whereas in 2020 they are predicted to reach $46 \%$ of total workforce population. Generation $\mathrm{Y}$ is a generation 
whose expectations, attitudes, and work values are significantly different from their senior generations (Anitha and Aruna, 2016). These differences may be caused by the digital technology, growing globalization, employment, and foreign investment (Liyanage \& Gamage, 2017).

Generation Y people are often popular as information savvy, have broad knowledge, and perform high multitasking skill (Tay, 2011). However, they are also known to be job hopper. When there is a lack of challenge in their work and once they feel bored, they tend to seek for other jobs in different companies (Ozcelik, 2015). Swiggard (2011) also mentioned that generation $\mathrm{Y}$ tend to move to other companies after working for one year. They reported higher level of turnover intention compared to generation $\mathrm{X}$ (Kowske et al, 2010). A survey of over 900 hospitality employees in Australia found that gen Y employees scored lower on commitment, while in contrary they display higher score on turnover intention (Solnet, Kralj, \& Kandampully, 2012).

Since it has often been regarded as a potential antecedent to actual turnover, turnover intention has received considerable attention in the literature (Oluwafemi, 2013). Apart from the correlation with actual turnover, turnover intention has also been found to be related to several other workrelated variables. For instance, turnover intention has been found to be negatively related to organizational commitment (Joo \& Park, 2010; Aydogdu \& Asikgil, 2010; Hussain \& Asif, 2012; Tirelli \& Goh, 2015).

Based on above explanation, researcher assumed that organization commitment among generation $\mathrm{Y}$ is probably low. This argumentation is relevant with Lub et al (2011) who mentioned that generation Y significantly show lower commitment than other generations. Researcher decided to work on organizational commitment because $40 \%$ of the variance in turnover intention was explained by it (Joo, 2010).

There are various antecedents of organizational commitment among working individuals. However, latest publications highlight the importance of psychological capital level in the employees' work-related attitudes and behavior.

Empirical studies support the impact of psychological capital on organization commitment. There was a significant positive relationship between the teachers' positive psychological capital levels and organizational commitment (Yalcin, 2016). Moreover, a meta-analysis has showed that psychological capital is an important predictor of commitment and other desirable outcomes (Avey et al, 2011). Psychological capital either directly or through work ethic variable mediator have affected organizational commitments (Hormozi \& Hajiloo, 2017). Psychological capital also significantly predicted affective organizational commitment among employees in oil industry in Iran (Ghaffaripour, 2015). Also in Iran, psychological capital is a significant predictor for organizational commitment among educational staff (Aminikhah, Khaneghah, \& Naghdian, 2016). In Turkey, psychological capital also found to be a significant predictor of organizational commitment and job satisfaction among employees in ministries and connected institutions (Cetin, 2011).

Etebarian, Tavakoli, and Abzari (2012) conducted a research about the relationship between psychological capital and organizational commitment. Among the three dimensions of organizational commitment, which includes affective, continuous, and normative commitment, only the relationship between psychological capital and affective commitment was significant. This result lead researcher to only use affective commitment as dependant variable.

Meyer and Allen (1991) have termed the three components as affective commitment, continuance commitment, and normative commitment, but this study focused on affective organizational commitment. Affective commitment has showed powerful correlations with desirable outcomes and organizations have nurtured this affective commitment among their employees (Meyer \& Allen, 1997; Meyer, et al, 2002). Jaros (1997) examined the effects of the three different types of commitment on turnover intention. He concluded that all three types of organizational commitment have a significant and negative relationship with turnover intentions, with affective commitment is the strongest predictor of all.

In addition, researcher found some studies that used affective commitment as a single measure of organizational commitment. Those researches were done by Lee and 
Bruvold (2003), Joo (2010), Joarder, Sharif, \& Ahmmed (2011), Ashar et al (2013), and Izzati, Suhariadi, \& Hadi (2015).

Researcher treated psychological capital as one construct and not as four different facets because Luthans et al (2007b) mentioned that the composite factor may be a better predictor of performance and satisfaction than the four single facets. Some studies (Cetin, 2011; Lather \& Kaur, 2015; Aminikhah, Khaneghah, \& Naghdian, 2016) have proven that psychological capital as one ultimate variable was a better predictor than either of its components for organizational commitment.

Organizational commitment refers to an individual's feelings about the organization as a whole. It is the psychological bond that an employee possess with an organization and has been found to be related to goal and value congruence, behavioral investments in the organization, and tendency not to leave the organization (Mowday et al., 1982). Three characteristics of organizational commitment are strong belief in and acceptance of the organization's goals and values, willingness to exert appropriate effort on behalf of the organization, and strong desire to stay in the organization.

Affective organizational commitment is specifically defined as "the employee's emotional attachment to, identification with, and involvement in the organization. Employees who have strong affective commitment continue employment with the organization because they want to do so (Meyer \& Allen, 1991).

Luthans, Youssef, \& Avolio (2007) explain psychological capital as psychological construct comprise of making positive attributions for now and future (optimism), trying to reach and seek for alternative ways to goals in order to succeed (hope), having belief of own competence to reach a certain set of goals (self-efficacy), and maintaining and bouncing back to reach goals even when facing problems and drawbacks (resilience).

Psychological capital as one of positive psychology variables focus positively on what is right with individuals, whereas classic psychological studies' point of view was more focusing at what is wrong with individuals (Seligman \& Csikszentmihalyi, 2000). Investing in and developing employees' psychological capital may be an important concern for today's organizations because psychological capital can be developed (Luthans et al, 2006),

Population of this current study is focusing on generation $\mathrm{Y}$ in Jakarta as capital city of Indonesia as well as country's business center. Researcher decided to focus only to Jakarta because Priawan (2017) mentioned that generation $\mathrm{Y}$ shares $40 \%$ of total population in Jakarta even since 2015 . This percentage is relatively bigger than the ones in another city in Indonesia.

Therefore, based on above arguments and explanations, this study was aimed to examine whether psychological capital could predict affective commitment among generation $\mathrm{Y}$ in Jakarta.

\section{METHOD}

This research can be categorized into cross-sectional (based on number of contact with participant), retrospective (based on its time reference), and non-experimental (based on its nature) study. People participated in this study were 183 male and female employees from different companies in Jakarta. They could join the study as long as they were born in 1980 to 2000. Purposive sampling was chosen to select the participants. Only those who fulfill the criteria could fill in the questionnaire. Participants had to be those who stayed in his or her company for minimum one year. Online questionnaire was utilised to support this study. Researcher randomly contacted some participants or checked their LindkedIn profile (if any) in order to minimize sampling error related to the participants' criteria. Shopping vouchers were given to randomly selected participants as a token reward

This study used two self-report scales to collect data, they are Affective Commitment Scale and Psychological Capital Scale. Both scales were adapted to Bahasa Indonesia from their English origin. Participants were asked to response to the scales given. Affective Commitment Scale was adapted from the Organization Commitment Scale developed by Meyer \& Allen (1990). As mentioned previously, researcher focused on affective commitment instead of normative and continuance commitment. Psychological Capital Scale was adapted from the Psychological Capital Questionnaire 
developed by Luthans, Youssef, \& Avolio (2007). It measures four constructs of psychological capital: self-efficacy, optimism, hope, and resilience.

Pilot study was executed to test scales' validity and reliability by using Rasch model with the help of Winstep 3.73. Sumintono \& Widhiarso (2014) mentioned validity criteria as follows:

Table 1. Validity criteria of Rasch Model

\begin{tabular}{ll}
\hline Criteria & Score \\
\hline Outfit Mean Square (MNSQ) & $.5<$ MNSQ $<1.5$ \\
Outfit Z-Standard (ZSTD) & $-2<$ ZSTD $<+2$ \\
Point Measure Correlation (Corr) & $.32<$ Corr $<.85$ \\
\hline
\end{tabular}

If an item could fulfill at least two of three above criteria, then it would be categorized as valid and usable item.

There will be three reliability indexes as the outcome of Rasch model, they are person reliability, item reliability, and Alpha Cronbach. Person reliability is used to test the ability of a scale in differentiating subjects with high and low score. Item reliability is used to test the ability of a scale in differentiating easy and difficult items. Alpha Cronbach is used to test scale's consistency in a whole as interaction between person and item.

Table 2. Reliability criteria of Rasch Model

\begin{tabular}{lc}
\hline \multicolumn{2}{c}{ Person reliability } \\
\hline Level of reliability & Score \\
\hline Weak & $.00-.67$ \\
Moderate & $.67-.81$ \\
Good & $.81-.91$ \\
Very good & $.91-.94$ \\
Outstanding & $.94-1.00$ \\
\hline \multicolumn{2}{c}{ Item reliability } \\
\hline Level of reliability & Score \\
\hline Weak & $.00-.67$ \\
Moderate & $.67-.81$ \\
Good & $.81-.91$ \\
Very good & $.91-.94$ \\
Outstanding & $.94-1.00$ \\
\hline \multicolumn{2}{l}{ Alpha Cronbach } \\
\hline Level of reliability & Score \\
\hline Very bad & $.00-.50$ \\
Bad & $.50-.60$ \\
Moderate & $.60-.70$ \\
Good & $.70-.80$ \\
Very good & $.80-1.00$ \\
\hline
\end{tabular}

Validity testing of Affective Commitment Scale resulted 7 valid items out of 8 items. Validity testing of Psychological Capital Scale resulted 23 valid items out of 24 items. Below is the detail.

Table 3. Validity testing result

\begin{tabular}{ccccc}
\hline \multicolumn{5}{c}{ Affective Commitment Scale } \\
\hline $\begin{array}{c}\text { Item } \\
\text { No }\end{array}$ & MNSQ & ZSTD & Corr & Result \\
\hline 1 & .64 & -1.5 & .87 & fit \\
2 & 1.43 & 1.6 & .31 & fit \\
3 & .78 & -.9 & .58 & fit \\
4 & 3.18 & 6.0 & -.18 & not fit \\
5 & .78 & -.7 & .58 & fit \\
6 & .69 & -1.3 & .74 & fit \\
7 & .76 & -1.0 & .72 & fit \\
8 & .54 & -2.3 & .84 & fit \\
\hline
\end{tabular}

\begin{tabular}{ccccc}
\multicolumn{5}{c}{ Psychological Capital Scale } \\
\hline $\begin{array}{c}\text { Item } \\
\text { No }\end{array}$ & MNSQ & ZSTD & Corr & Result \\
\hline 1 & & & & \\
2 & .57 & -1.8 & .73 & fit \\
3 & .73 & -1.0 & .75 & fit \\
4 & .58 & -1.8 & .74 & fit \\
5 & .67 & -1.3 & .75 & fit \\
6 & .89 & -.3 & .56 & fit \\
7 & .89 & -.3 & .56 & fit \\
8 & .39 & -3.0 & .81 & fit \\
9 & 1.28 & 1.0 & .48 & fit \\
10 & 1.09 & .4 & .59 & fit \\
11 & .66 & -1.4 & .71 & fit \\
12 & .36 & -3.2 & .84 & fit \\
13 & 1.10 & .5 & .62 & fit \\
14 & .99 & .0 & .65 & fit \\
15 & 1.58 & -2.3 & .78 & fit \\
16 & 1.02 & 1.9 & .49 & fit \\
17 & 1.32 & .2 & .62 & fit \\
18 & 1.13 & .6 & .60 & fit \\
19 & 1.00 & .1 & .55 & fit \\
20 & 3.79 & 6.9 & .26 & fit \\
21 & .79 & -.7 & .66 & fit \\
22 & 1.03 & .2 & .61 & fit \\
23 & 1.59 & 2.1 & .48 & fit \\
24 & 1.21 & .8 & .50 & fit \\
\hline & & & &
\end{tabular}

Next, reliability testing result of both scales can be seen as follows. All scales show satisfying reliability on three indexes. 
Table 4. Reliability testing result

\begin{tabular}{ll}
\multicolumn{2}{c}{ Psychological Capital Scale } \\
\hline Reliability & Score \\
\hline Person reliability & .89 \\
Item reliability & .75 \\
Alpha Cronbach & .92 \\
\hline \multicolumn{2}{c}{ Affective Commitment Scale } \\
\hline Reliability & Score \\
\hline Person reliability & .74 \\
Item reliability & .86 \\
Alpha Cronbach & .82 \\
\hline
\end{tabular}

SPSS version 23 was then used to analyze data by using simple regression analysis to examine the proportion of variance in affective commitment predicted from psychological capital.

\section{RESULTS AND DISCUSSION}

Participants were $60 \%$ female and $40 \%$ male. Moreover, majority of respondents were staff $(65 \%)$, permanent $(72 \%)$, have worked for 1-3 years (47\%), and hold Bachelor degree (76\%).

Table 5. Demographic Data

\begin{tabular}{|c|c|c|c|}
\hline \multirow{3}{*}{$\begin{array}{l}\text { Variable } \\
\text { Gender }\end{array}$} & Category & \multicolumn{2}{|c|}{ Percentage } \\
\hline & \multirow{2}{*}{$\begin{array}{l}\text { Male } \\
\text { Female }\end{array}$} & & 40 \\
\hline & & & 60 \\
\hline \multirow[t]{3}{*}{ Job level } & Staff & & 65 \\
\hline & Supervisor & & 30 \\
\hline & Manager & & 5 \\
\hline \multirow{2}{*}{$\begin{array}{l}\text { Employment } \\
\text { Status }\end{array}$} & Permanent & & 72 \\
\hline & Contract & & 28 \\
\hline \multirow[t]{4}{*}{ Tenure } & $<1$ year & & 30 \\
\hline & $1-3$ years & & 47 \\
\hline & $3-5$ years & & 18 \\
\hline & $>5$ years & & 5 \\
\hline \multirow{3}{*}{$\begin{array}{l}\text { Educational } \\
\text { degree }\end{array}$} & Diploma & & 9 \\
\hline & Bachelor & & 76 \\
\hline & Master & & 15 \\
\hline \multicolumn{4}{|c|}{$\begin{array}{l}\text { Participants' score in psychological } \\
\text { capital and affective commitment can be seen } \\
\text { in table } 6 .\end{array}$} \\
\hline \multicolumn{4}{|c|}{ Table 6. Participants' scores } \\
\hline & $X \max \quad \mathrm{Xmin}$ & Mean & SD \\
\hline $\begin{array}{l}\text { Affective } \\
\text { commitment }\end{array}$ & 34 & 21.33 & 3.702 \\
\hline $\begin{array}{l}\text { Psychological } \\
\text { capital }\end{array}$ & 135 & 102.33 & 11.833 \\
\hline
\end{tabular}

Next, table 7 presents the categorization used in affective commitment and psychological capital.

Table 7. Score categorization of affective commitment and psychological capital

\begin{tabular}{lllll}
\hline Category & Norm & $\begin{array}{l}\text { Score } \\
\text { Aff Com }\end{array}$ & Total & $\%$ \\
\hline High & $(\mu+1.0 \sigma) \leq X$ & $X \geq 25.032$ & 46 & 18 \\
Moderate & $(\mu-1.0 \sigma) \leq X$ & $17.628<X<$ & 166 & 66 \\
& $<(\mu+1.0 \sigma)$ & 25.032 & & \\
Low & $X<(\mu-1.0 \sigma)$ & $X \leq 17.628$ & 39 & 16 \\
\hline Category & Norm & Score & Total & $\%$ \\
& & Psy Cap & & \\
\hline High & $(\mu+1.0 \sigma) \leq X$ & $X \geq 114.163$ & 55 & 15.9 \\
Moderate & $(\mu-1.0 \sigma) \leq X$ & $90.497<X<$ & 147 & 63.1 \\
& $<(\mu+1.0 \sigma)$ & 114.163 & & \\
Low & $X<(\mu-1.0 \sigma)$ & $X \leq 90.497$ & 49 & 21.0 \\
\hline
\end{tabular}

Hypothesis testing was executed after confirming that data is normal and linear. Simple regression analysis showed that psychological capital correlates positively to affective commitment. Hypothesis testing result shows correlation coefficient number of $\mathrm{r}_{\mathrm{xy}}=.138$ with significance $\mathrm{p}=.000(\mathrm{p}<.05)$. Positive mark in correlation coefficient shows that the higher one's psychological capital level then his or her affective commitment could increase. Sig F Change score is .028 which means psychological capital is significant in predicting affective commitment. Therefore, hypothesis is accepted. However, determination coefficient score $\left(\mathrm{R}^{2}\right)$ in this research is 0,020 so that effective contribution from psychological capital to affective commitment is $2 \%$, while the rest $98 \%$ could be affected by other variables that are not measured in this research. This research did not control the effect of other variables statistically. Some variables may be age, job level, employment status, tenure, educational degree, and work location. The very small contribution may be less meaningful for practical implication.

It is hypothesized that psychological capital could predict affective commitment significantly. Result shows that the hypothesis is accepted but researcher would like to deliver more arguments regarding the very small determinant coefficient score. This condition is different than previous researches from another country as based on previous studies psychological capital was found to predict affective commitment and the determinant coefficient score was satisfying. 
Looking at the result, researcher would like to highlight some points to be discussed. First, although the determination coefficient score is small, at least this research has proven that psychological capital still correlates positively to affective commitment. Second, looking at the weak correlation score as well as small contribution, there could be some possibilities. Researcher assumed that there may be an intervening variable between psychological capital and affective commitment that can enhance determinant coefficient score of affective commitment among the population of generation $\mathrm{Y}$ in Indonesia.

Third, most participants are in moderate level of affective commitment. This is contradictive with the researcher's previous assumption. Most of participants also have worked for one to three years, as opposed to less than a year. This matter may be caused by participants' subjective response to affective commitment scale.

As mentioned by Hormozi \& Hajiloo (2017), psychological capital could affect organizational commitment either directly or through work ethic variable as mediator. They measure the whole three types of commitment (affective, continuance, and normative) as termed by Meyer and Allen (1991), whereas this research focused only on affective commitment.

Several limitations were encountered during the research process. First, the number of the sample used in this study is very small $(n=233)$ in contrast to the total generation $Y$ population in Indonesia. Participants' type of companies are also homogeneous, namely private companies, whereas there are still so many generation $\mathrm{Y}$ working in state owned companies or working as public servants. These may lead to lesser accuracy in result generalization. Second, self report measure in this research is still potential to bias due to its attitudinal nature.

\section{CONCLUSION AND SUGGESTION}

Based on the analysis, it can be concluded that psychological capital statistically can predict affective commitment among generation $\mathrm{Y}$, but in the context of Indonesian culture, another variable may be combined with psychological capital for better practical purpose.
As a practical suggestion, companies may conduct psychological capital training combined with other variables to enhance their employees' affective commitment especially generation Y. As for next research, there are some suggestions. First, it is proven that contribution of psychological capital to affective commitment is very small, so it is important to explore possible intervening (mediator) variables. This research gives opportunity for next researchers to test the underlying mechanism between psychological capital and affective commitment in the context of Indonesian culture. Second, bigger samples may also lead to better population representativeness. Third, deeper literature reviews are needed before conducting any research on psychological capital and affective commitment. Characteristics of participants have to be explored as well. Longitudinal attempt as well as multi rating method could be useful in collecting data. Last, another way to control for socially desirable responding is to include "filler" items (Morling, 2012). Some surveys mask the true purpose of a sensitive survey by including several unrelated filler items about racial attitudes, politics, or gender role.

\section{REFERENCES}

Aminikhah, H., Khaneghah, T. M., \& Naghdian, M. (2016). The relationship of psychological capital and job satisfaction with organizational commitment. International Journal of Information, Business, and Management, 8 (1), 153-162.

Anitha, J., \& Aruna, M. (2016). Enablers of employee engagement of gen $\mathrm{Y}$ at the workplace with reference to automobile sector. Amity Journal of Training and Development, 1(1), 93-108.

Ashar, M., Ghafoor, M. M., Munir, E., \& Hafeez, S. (2013). The impact of percepstions of training on employee commitment and turnover intention: evidence from Pakistan. International Journal of Human Resource Studies, 3 (1), 74-79.

Avey, J. B., Reichard, R. J., Luthans, F. and Mhatre, K. H. (2011). Meta-analysis of the impact of positive psychological capital on employee attitudes, 
behaviors, and performance, Human Resource Development Quarterly, 22 (2), 127-152.

Aydogdu, S. \& Asikgil, B. (2010). An empirical study of the relationship among job satisfaction, organizational commitment, and turnover intention. International Review of Management and Marketing. 1(3), 43-53.

Cetin, F. (2011). The effects of the organizational psychological capital on the attitudes of commitment and satisfaction: a public sample in Turkey. European Journal of Social Sciences, 21(3). 373-382.

Delcampo, R. G., Haggerty, L. A, Haney, M. J., \& Knippel, L. A. (2011). Managing the multigenerational workforce: From the GI generation to the millennials. Burlington: Gower Publishing Company.

Etebarian, A., Tavakoli, S., \& Abzari, M. (2012). The relationship between psychological capital and organizational commitment. African Journal of Business Management, 6 (4), 50575060.

Ghaffaripour, S. (2015). Prediction of Affective Organizational Commitment Based on Employee Characteristics and Psychological Factors among Oil Personnel. International Journal of Management and Business Research, 5(4), 337-350.

Hormozi, M. K \& Hajiloo, S. (2017). Development of an organizational commitment model for Mapna MD2 Co. based on psychological capital and work ethic. European Journal of Social Sciences Studies, 2 (4), 14-21.

Hussain, T. \& Asif, S. (2012). Is employee's turnover intention driven by organizational commitment and perceived organizational support? Journal of Quality and Technology Management, 8 (2), 01-10.

Izzati, U. A., Suhariadi, F., \& Hadi, C. (2015) Personality trait as predictor of affective commitment. Open Journal of Social Sciences, 3, 34-39.

Jaros, S. J. (1997). An Assessment of Meyer and Allen's three-component model of organizational commitment and turnover intentions. Journal of Vocational Behavior, 51, 319-337.
Joarder, M. H. R., Sharif, M. Y., \& Ahmmed, K. (2011). Mediating role of affective commitment in HRM practices and turnover intention relationship: a study in a developing context. Business and Economics Research Journal, 2(4), 135158.

Joo, B. (2010). Organizational commitment for knowledge workers: the roles of perceived organizational learning culture, leader-member exchange quality, and turnover intention. Human Resource Development Quarterly, 21 (1), 69-85.

Joo, B. \& Park, S. (2010). Career satisfaction, organizational commitment, and turnover intention: the effects of goal orientation, organizational learning culture, and developmental feedback. Leadership \& Organization Development Journal, 31 (6), 482-500.

Kowske, B. J., Rasch, R., \& Wiley, J. (2010). Millennials' (lack of) attitude problem: an empirical examination of generational effects on work attitudes. Journal of Business and Psychology, 25, 265-279.

Lather, A. S. \& Kaur, S. (2015). Psychological capital as predictor of organizational commitment and Organizational Citizenship Behavior. The International Journal of Indian Psychology, 2(4). 158-162.

Lee, C. H. \& Bruvold, N. T. (2003), Creating value for employees: investment in employee development. International Journal of Human Resource Management, 14 (6), 981-1000.

Liyanage, H. M. \& Gamage, P. (2017). Factors influencing the employee engagement of generation Y employees. In Proceedings of APIIT Business \& Technology Conference. Colombo.

Lub, X., Bijvank, M. N., Bal, P. M., Blomme, R., \& Schalk, R. (2011). Different or alike? Exploring the psychological contract and commitment of different generations of hospitality workers. International Journal of Contemporary Hospitality Management, 24 (4), 553573.

Luthans, F., Avey, J. B., Avolio, B. J., Norman, S. M. and Combs, G. M. (2006). Psychological capital development: toward a micro- 
intervention. Journal of Organizational Behavior, 27, 387-393.

Luthans, F., Avolio, B. J., Avey, J. B., \& Norman, S. M. (2007b). Positive psychological capital: measurement and relationship with performance and satisfaction. Personnel Psychology, 60, 541-572.

Luthans, F., Youssef, C. M., \& Avolio, B. J. (2007). Psychological capital: developing the human competitive edge. New York: Oxford University Press.

Meyer, J. P. \& Allen, N. J. (1990). The measurement and antecedents of affective, continuance and normative commitment to the organization, Journal of Occupational Psychology, 63, $1-18$

Meyer, J. P. \& Allen, N. J. (1991). A three component conceptualization of organization commitment. Human Resource Management Review, 1 (1), 61-89.

Meyer, J. P. and Allen, N. J. (1997), Commitment in the workplace: theory, research, and application. California: Sage Thousand Oaks.

Morling, B. (2012). Research methods in psychology: evaluating a world of information. New York: W. W. Norton \& Company, Inc.

Mowday, R., Steers, R. and Porter, L. (1982), Employee-organization linkages: the psychology of commitment, absenteeism, and turnover. New York: Academic Press.

Meyer, J. P., Stanley, D. J., Herscovitch, L., \& Topolnytsky, L. (2002). Affective, continuance, and normative commitment to the organization: a meta analysis of antecedents, correlates, and consequences. Journal of Vocational Behavior, 61, 20-52.

Oluwafemi, O. J. (2013). Predictors of turnover intention among employeees in Nigeria's oil industry. Organisations and markets in the emerging economies, $4(2), 42-63$.

Ozcelik, G. (2015). Engagement and retention of the millennial generation in the workplace through internal branding. International Journal of Business and Management, 10 (3), 99-107.

Priawan, R. (2017, Feb 6). Tahun 2020 generasi Millennial akan Mengubah
Indonesia. Retrieved on 28 April 2019

from https://www.idntimes.com/ business/economy/radit-pratamapriawan/tahun-2020-generasimillennial-akan-mengubahindonesia-c1c2/full

Seligman, M. E. P. \& Csikszentmihalyi, M. (2000). Positive psychology. American Psychologist, 55, 5-14.

Solnet, D., Kralj, A., \& Kandampully, J. (2012). Generation Y employees: an examination of work attitude differences. The Journal of Applied Management and Entrepreneurship, 17 (3). 36-41.

Sumintono, B. \& Widhiarso, W. (2014). Aplikasi model Rasch untuk penelitian ilmu-ilmu sosial. Cimahi: Trim Komunikata Publishing House.

Swiggard, S. (2011). Generations and employee commitment: An exploration of the impact of changes in technology, home and family structure, and employer-employee relationship. Unpublished Dissertation. Capella University.

Tay, A. (2011). Managing generational diversity at the workplace: Expectations and perceptions of different generations of employees. African Journal of Business Management, 5(2), 249-255.

Tirelli, A. \& Goh, S. C. (2015). The relationship between trust, learning capability, affective organizational commitment and turnover intentions. International Journal of Human Resources Development and Management, 15(1), 54-68.

Yalcin, S. (2016). Analyzing the relationship between positive psychological capital and organizational commitment of the teachers. International Education Studies, 9 (8), 75-83. 